\title{
FOREST MANAGEMENT AND ENVIRONMENTAL LAW ENFORCEMENT POLICY AGAINST ILLEGAL LOGGING IN INDONESIA
}

\author{
Wahyu Nugroho \\ Faculty of Law, Sahid University Jakarta \\ Jl. Prof. Dr. Soepomo, SH. No. 84 Tebet, South Jakarta, DKI Jakarta, Indonesia \\ Mas Subagyo Eko Prasetyo \\ Faculty of Law, National University, Jakarta \\ J1. Sawo Manila, Pejaten Pasar Minggu Jakarta 12520, Indonesia
}

\begin{abstract}
Indonesia's forests have now been severely damaged. This condition is caused by various things such as illegal logging, encroachment, forest fires, and others. The root of the problem is the not yet realized good forest governance, so that it becomes a problem about how the current forest management policy? How to enforce environmental law on forest destruction due to illegal logging. The results of the study are firstly, in forest management through Law Number 41 of 1999 concerning Forestry and the provisions on eradicating forest destruction, can be re-established between the government and local communities, in order to place its function in the same view, the government bringing business actors can respect the system local people's lives and vice versa the community can understand the importance of development in the area and can improve the standard of living of the community; secondly, environmental law enforcement for forest destruction due to illegal logging through criminal law is a strict enforcement of the implementation of environmental laws and laws on prevention, eradication and destruction of forests that are oriented to the function of law as a means of carrying out social engineering, which includes the formulation of criminal acts, criminal liability, and sanctions.
\end{abstract}

Keywords: forest, illegal logging, law enforcement, management, environment

Cite this Article: Wahyu Nugroho and Mas Subagyo Eko Prasetyo, Forest Management and Environmental Law Enforcement Policy against Illegal Logging in Indonesia, International Journal of Management, 10 (6), 2019, pp. 317-323.

http://iaeme.com/Home/issue/IJM?Volume $=10 \& I s s u e=6$ 


\section{INTRODUCTION}

The existence of forests has urgency in the lives of humans and other living things. Forests protect water reserves and provide oxygen. According to data obtained from WWF Indonesia's tropical forests are home and the last hiding place for the world's unique biological wealth. The biodiversity contained in Indonesia's forests includes 12 percent of the world's mammal species, 7.3 percent of reptile and amphibian species, and 17 percent of bird species from around the world (WWF, 2019). Indonesia's forests are the third largest in the world with tropical forests and contributions from the rain forests of Kalimantan and Papua. According to Forest Watch Indonesia (FWI) data, an independent Indonesian forest monitoring agency, 82 hectares of Indonesia's land area are still covered by forests (Arifin, 2019).

Forest burning and illegal logging activities pose a threat to the ecological function of Indonesia's tropical forests. Illegal logging that occurred in Indonesia has a very broad impact on environmental conditions as well as the continuity of its functions for the lives of various communities across generations. The threat of drought, the danger of floods, landslides, and fires, depletion of the ozone layer, global warming and climate change pose a threat to the sustainability and sustainability of human life. The weak aspects of supervision (control) and law enforcement (law enforcement) in Indonesia, the exploitation of forest resources that is out of control and untouched by the law (Yusuf and Makarao, 2011).

Indonesia's forests have now been severely damaged. This condition is caused by various things such as illegal logging (illegal logging), encroachment, forest fires, and others. The root of the problem is the not yet realized good forest governance. Good forest governance will be realized by improving various aspects that support it such as forest management techniques, forestry human resources (integrity, intellectuality, and morals), and the level of security and supervision as well as legislative devices. Indonesia is a country rich in natural resources. This great wealth (especially forests) for more than 3 decades of the New Order government was mostly managed by large entrepreneurs who were given Forest Concession Rights (HPH).

As a result the enthusiasm contained in the Indonesian constitution Article 33 paragraph 3 of the 1945 Constitution states that the earth, water and natural resources contained therein are controlled by the state and used for the amount of prosperity of the people is difficult to realize, although recognized contribution to macro-economic development is quite large. In the late 1970s after we welcomed FAO's call to start thinking about Forest for Local Community Development, among others, by supporting the theme of Forest for People, at the VIII World Forestry Congress in Jakarta, still the people and community aspects did not receive serious attention, even more low from the environmental aspect in every government policy.

Illegal logging as a form of violation of human rights, from an economic standpoint, illegal logging that has occurred has caused losses in state finances, namely reducing state foreign exchange revenues and state revenues. Besides illegal logging also resulted in various adverse impacts, namely the threat of the de-industrialization process of the forestry sector. In the 1945 Constitution Article $28 \mathrm{H}$ (1) says that "everyone has the right to live in physical and spiritual prosperity, to live, and to get a good and healthy environment and to have health services." Although the 1945 Constitution has mandated that everyone has the right to live in physical and spiritual prosperity, live and have a good and healthy living environment and are entitled to health services. The problem in this paper is first, what is the current management policy or forest governance system? And second, how is environmental law enforcement for the destruction of forests due to illegal logging? 


\section{DISCUSSION}

\subsection{Current Forest Management Policy in Indonesia}

The control of natural resources, including those in Indonesia's forest areas, is generally dominated by large entrepreneurs with the strength of their capital. They obtained concession rights or usufructuary rights over a very long period of decades, and generally could be extended. Meanwhile, local people who have lived and relied on their lives for generations from forest resources in the same area have been denied their rights. This disparity in the distribution of natural resources is often a source of structural and social conflict in communities in forest areas. Conflicts also occur between the government and the people due to lack of coordination between related agencies in the field of land, for example there is no synchronization between one sector with another sector, many regulations but are not effective (Kalo, 2006).

Various national regulations issued by the state at present Law No. 41 of 1999 concerning Forestry, Law No. 18 of 2013 concerning Prevention and Eradication of Forest Destruction and Law No. 32 of 2009 concerning Environmental Protection and Management, but the fact remains destruction of forests, which can then lead to an ecosystem balance. The way forest management is still not good or the system of forest management, will result in illegal logging behavior, and the impact of the future is environmental damage or ecosystem damage.

The state tends to prioritize or prioritize the granting of rights to corporates or financiers on behalf of the development or growth of the national economy, so that people often experience eviction from the land or resources they have or claim before. Examples of agrarian disputes as excesses of the implications of the right to control the State have been widely studied and published so far, including the North Sumatra Foundation for Synthesis \& Farmers' Union, Bachriadi\& Lukas 2007 report, and Bosko (2006) who wrote about the rights of indigenous peoples which is marginalized in the context of natural resource management (Bosko, 2006). In the context of forestry, BudiHarsonosaid that both Law Number 5 of 1967 and Law Number 41 of 1999 did not even clearly recognize the existence of customary land rights of indigenous peoples within the forest area (Harsono, 2008).

In terms of land tenure, the government and local communities need to be resettled, especially forest management with various types of forests based on their ownership, namely rights forests and state forests regulated through Law Number 41 of 1999 concerning Forestry. What should be a contradiction in terms of land tenure is not necessary if each party consisting of the government and the local community can put its function to the same view, in the sense that the government that brings corporate must be able to respect the life systems of the local community and vice versa the community can understand the importance of development in their area and can improve the standard of living of the community (Yamin, 2003). In the context of forestry, the elaboration of the state's right to control in Article 33 of the 1945 Constitution is formulated in the Forestry Law, the formulation of which is the same as the agrarian basic law determining all forests in the territory of Indonesia including the natural resources contained therein controlled by the State for the greatest prosperity of the people.

The definition of being controlled by the State does not mean that it is owned, but rather an understanding that contains obligations and authorities in public law (Salim, 2008). Forest management, control and utilization policy in Article 4 paragraph (1) of Law no. 41 of 1999 concerning Forestry, the phrase "controlled" in the Article is not meant to be "owned", but the state as a juridical constitutional legal authority obtains the mandate in the form of authority to make arrangements to create legal certainty and social order. Formulation of Article 4 paragraph (2) of Law No. 41 of 1999 concerning Forestry explicitly explains the obligations and authority of a country to regulate forest natural resources (Nugroho, 2014). 
The involvement of stakeholders in the formulation of policies on management of forest resources is something that must be done as well as possible so that good governance can be realized. Stakeholders can collaborate in formulating a policy. Judith E. Innes and David E. Booher provide an explanation of collaborative policymaking as follows:

"... collaborative policymaking as not just a method which can solve problems when there is conflict in the traditional policy system. It is, even more important, a way to establish new networks among the players in the system and increase the distribution of knowledge among these players. This includes knowledge of each other's needs and capabilities and the dynamics of the substantive problems in society, whether in transportation, environment or housing policy. Collaborative planning, we contend, has emerged as a highly adaptive and creative form of policymaking and action in the Information Age. It is an emerging mode of governance" (Innes and Booher, 2003).

Based on the division of authority between the center and the regions regulated in Law No. 23 of 2014 concerning Regional Government, in relation to the distribution of forest management affairs, is regulated Article 14 which states that the administration of government affairs in the field of forestry, maritime affairs, as well as energy and mineral resources is shared between the Central Government and Provincial Regions and for Government Affairs in the field of forestry related with the management of regency / municipal grand forest parks it becomes the authority of regency / city regions. From these laws and regulations, it can be seen that forest management is not only the authority of the central government but also the Regional Government, even the portion of regional government authority is greater to manage the natural resources in the area.

Provisions in the distribution of functions governed by local government law shows that coordination, cooperation, monitoring and control are mechanisms in creating good forest management. This is in line with the function of the Ministry of Forestry which is currently the Ministry of Environment and Forestry in the supervision and transfer of authority as stipulated in Law No. 41 of 1999 concerning Forestry, forest governance must be able to separate explicitly between the authority of policy makers in the context of state administration and forest management at the site level to encourage the development of forest management best practices. The division of administrative authority (decentralization) to regional governments is encouraged to enhance the role of forestry in regional / regional development.

Forest management activities are often manifested in various forms of activities to utilize and maintain forests. Utilization of forest resources can be in the form of harvesting wood and non-timber products from the forest. While maintenance is carried out by maintaining the quantity and quality of forest biophysics and maintaining the continuity of the functioning of the forest. In line with the current mission of forest management by the state which in addition to striving to preserve the forest ecosystem also helps to improve the welfare of the community, especially those living around the forest, forest management activities must include at least two kinds of interest's namely ecological and social interests (Siswoko, 2010)

Forest sustainability will be in line with the economic prosperity of the people and the authority of the government in carrying out the mandate of the constitution to control the lives of many people. This provides a clue that forest resource management policies in the region must at least be formulated with consideration that ecological and social interests must be synergized appropriately (Irawanto, 2013).

\subsection{Law Enforcement of Illegal Logging in Indonesia}

One of the causes of forest destruction is illegal logging. The practice of illegal logging or illegal logging has become an important issue, even now it has become a vocabulary that the problem is not all people understand it correctly and the definition of illegal logging itself is 
therefore very important to build understanding of the construction of definition / understanding of illegal logging. The definition of illegal logging itself when seen in various laws, among others: literally the term illegal logging comes from English in the Contemporary English Indonesia Dictionary (Narindrani, 2018).

Illegal's Black Law Dictionary means "Forbiddinbay Law, Unlanwful." This means that which is prohibited by law or illegitimate, whereas Logs in English means "logs", and logging means logging and carrying sawn. Environmental crime is categorized as a crime in the economic field in the broadest sense, because the scope of crime and environmental violations is broader than other conventional crimes, the impact of which results in tremendous economic losses to the country, as well as the impact on environmental damage. Illegal logging, experienced a boom in the period 1999 to 2004 (Helmi, 2012). Examples of illegal logging carried out by timber entrepreneurs from Medan Adelin Lis, have been detrimental to the state finances of almost around Rp.227.02 trillion, while environmental damage can be seen from the illegal deforestation that took place from 1967 has resulted in forest damage in Indonesia reached 1,8 million hectares per year although on the other hand can increase the country's foreign exchange. In Sumatra the total decrease in forest area from 23 million ha to 16 million ha, where South Sumatra and Jambi are recorded as the fastest decreasing forest area. In Kalimantan the total decline in forest area from 40 million ha to 30 million ha (Siregar and Zul, 2015).

Illegal logging on a large scale is carried out by outsiders (entrepreneurs) involving local communities and supported by unscrupulous officials. Supporting communities see this phenomenon as an alternative source of new economy in meeting the need for land and obtaining additional income (Surono, 2008). Various cases in a number of areas where a person simply fulfills the economic needs of felling, extracting and carrying a piece of wood from the forest without the permission of the authorized official to be subjected to illegal logging in the context of criminal purposes for crime prevention as a means of protecting the community to achieve justice and prosperity society (social welfare). Illegal logging is a form of green crime (green criminology). The concept of destruction in the literature "green criminology" is said that the determination of destruction is framed by a different eco-philosophy and analysis approach (Kusumawardhani, 2019).

According to "green criminology", destruction is conceptualized in relation to humans, the environment in general, and animals. From a "green criminology" perspective, law is often seen as an arena of disagreement and intense competition because of the powerlessness of criminal sanctions in relation to the type of specific activity or violation. Carrabine discusses environmental crime in relation to primary and secondary crime (Beirne and South N., 2007). Illegal logging as part of a green crime must take action in law enforcement. Green crimes are broadly defined simply as crimes against the environment. Primary crimes are actual crimes, which directly result in the destruction and degradation of the earth's resources, through human actions (for example illegal logging). Secondary crimes or symbiotic green crimes are crimes that develop out of social reprimands that stem from rules that seek to regulate disasters about the environment, such as illegal, toxic waste.

Good prevention of environmental crime must touch the interests of humans, the environment and animals. The basic principle of crime prevention needs to be guided by consideration of the ecological balance and from a human perspective, ecological citizenship. Thus, human law and human rights must be softened by recognition, where human interests are intimately related to the welfare of the planet as a whole. Human intervention, about everything, needs to be considered from this angle. Green criminology provides the mandate that one must help foster attention, analysis and greater action in paying attention to environmental damage. From the point of view of preventing environmental crime, the task is both instrumental and 
symbolic. We want to enter into a place of strategy that protects certain people, places and creatures. At the same time, we want to signal to the community as a whole that a particular project is significant and that through that it states our collective value about "what is valuable". For example, the establishment of a "green zone" in a particular region is important, not only because it excludes certain areas of human interaction, but it also sends a strong message that ecological safety is important.

The impact of ecological (environmental) damage due to illegal logging (illegal logging) according to various studies conducted by environmental and forestry experts that various natural disasters that occur, allegedly as a result of forest destruction as a result of illegal logging (illegal logging). In addition to natural disasters, illegal logging also causes damage to flora and fauna and the extinction of endangered species. Since the issuance of the second amendment to the Law on Environmental Protection and Management No. 32 of 2009, the function as umbrella provisions is attached to these provisions, including law enforcement. Enforcement of environmental law on forest destruction due to illegal logging through criminal law is a strict enforcement of the implementation of environmental laws and laws on prevention, eradication and destruction of forests that are oriented to the function of law as a means to carry out social engineering, namely which includes the formulation of criminal acts (criminal act), criminal liability, and sanctions (sanction).

National environmental laws bring fundamental changes in environmental management arrangements in Indonesia. In general explanation, viewing criminal law as a last resort (ultimum remidium) for certain formal criminal acts, while for other criminal acts stipulated in addition to Article 100, the ultimum remedium principle, which applies the premium remedium principle (prioritizes the implementation of criminal law enforcement ). The principle of ultimum remedium places criminal law enforcement as the last choice of law. Dependence on the application of criminal law is based on the state of administrative sanctions that have been imposed not obeyed, or violations committed more than once. Law enforcement for environmental management is still difficult because of the difficulty in proving and determining the standard criteria for environmental damage.

Enforcement of environmental law in relation to illegal logging through criminal law is the main problem in the criminal law as outlined in the law which more or less has a role to carry out social engineering, which includes the formulation of criminal acts, criminal liability, and sanctions both criminal and disciplinary. In accordance with the objectives not only as a means of order, environmental law also contains the purpose of community renewal (social engineering). Law as a social engineering tool is very important in the enforcement of environmental law in the forestry sector, especially illegal logging.

\section{CONCLUSIONS}

Based on the above descriptions can be summarized as follows. First, Policies on forest management through Law Number 41 of 1999 concerning Forestry and provisions regarding eradication and destruction of forests, can be resettled between the government and local communities, in order to place their functions for the same view, in the sense of the government bringing business actors to can respect the life system of the local community and vice versa the community can understand the importance of development in their area and can improve the standard of living of the community.

Second, Enforcement of environmental laws on forest destruction due to illegal logging through criminal law is a strict enforcement of the implementation of environmental laws and laws on prevention, eradication and destruction of forests that are oriented to the legal function as a means to carry out social engineering, which includes the formulation of criminal acts, criminal liability, and sanctions. 


\section{REFERENCES}

[1] Arifin, Nurul. https://www.goodnewsfromindonesia.id/2018/01/12/how-forests-indonesiaas-paru-paru-dunia-di-masa-depan accessed on October 10, 2019.

[2] Beirne and South N. (Eds.), Issues in Green Criminology: Confronting Harms against Environments, Humanity and Other Animals. Devon: Willan Publishing, 2007

[3] Bosko, Rafael Edy, Rights of Indigenous Peoples in the Context of Natural Resource Management, Jakarta: Elsam Publisher, 2006

[4] H.S., Salim., Fundamentals of Forestry Law. Jakarta: SinarGrafika, 2008

[5] Harsono, BoediHarsono, Indonesian Agrarian Law, History of the Establishment of LoGA, Contents and Implementation. Delay Publisher, 2008

[6] Helmi, Environmental Licensing Law. Cet I, Jakarta: SinarGrafika, 2012

[7] Innes, et al, Collaborative Policymaking: Governance through Dialogue. In Maartin A. Hajer and Hendrick Wagenaar, (Eds.), Deliberative Policy Analysis, Understanding Governance in the Network Society, New York-USA: Cambridge University Press, 2003

[8] Irawanto, Dhedhi. "Construction of Multi stakeholder Forest Resource Management Policy in Jombang Regency". Journal of Public Administration Networks. Th V. Number 2.Surabaya: Faculty of Social and Political Sciences, Airlangga University, July-December 2013

[9] January Siregar and Muaz Zul. "Law Enforcement in Environmental Crimes in Indonesia". Mercatoria Journal, Medan: Postgraduate Master's Program in Law, Medan Area University, Vol. 8. No. 2. December 2015

[10] Kalo, Syafruddin, Land Issues in North Sumatra ", in the book Land Disputes and Alternative Solutions, Medan: CV Cahayallmu, 2006

[11] Kusumawardani, DyahTriretnoPrasetya, http://ditjenpp.kemenkumham.go.id/hukumlingkungan/744- damage- environment- and-preventive- crime.html accessed on October $10,2019$.

[12] Narindrani, Fuzi. "Community Efforts in the Prevention and Eradication of Illegal Logging in Indonesia". De Jure's Legal Research Journal, Jakarta: Indonesian Law Researchers Association (IPHI) in collaboration with the Legal and Human Rights Research and Development Agency Ministry of Law and Human Rights of the Republic of Indonesia. Vol. 18. No. 2. June 2018.

[13] Nugroho, Wahyu. "Constitutionality of Indigenous Peoples Rights in Managing Customary Forests: Empirical Facts of Legalization of Licensing". Constitutional Journal, Jakarta: Secretariat General and Registrar of the Constitutional Court of the Republic of Indonesia, Volume 11. Number 1. March 2014

[14] Siswoko, B. D., Good Forest Governance: Model of State Forest Management in GunungKidul Regency. Yogyakarta: Thesis of Master of Science Postgraduate Program in Gadjah Mada University, 2009

[15] Surono, Agus, Collaborative Settlement of Forest Resource Conflicts (Partnerships). Cet I. Jakarta: Faculty of Law, Al-Azhar University, 2008

[16] Wwf.https://www.wwf.or.id/about_wwf/oper_kami/forest_spesies/about_forest_spesies/k ehforest/ accessed on 10 October 2019.

[17] Yamin, Muhammad, Some Philosophical Dimensions of Agrarian Law, Medan: Pustaka Bangsa Press, 2003 